\title{
Do different pedagogical conceptions result in different quality of life levels?
}

\author{
(D) Oscarina da Silva Ezequie/1 \\ (D) Bianca Sakamoto Ribeiro Paiva ${ }^{2}$ \\ (iD) Alessandra Lamas Granero Lucchetti \\ (iD Carlos Eduardo Paiva ${ }^{2}$ \\ (D) Ivana Lúcia Damásio Moutinho \\ (iD) Robson Aparecido dos Santos Boni ${ }^{3}$ \\ (iD) Giancarlo Lucchetti ${ }^{1}$
}

1. Faculdade de Medicina, Universidade Federal de Juiz de Fora, Juiz de Fora, Brasil. 2. Hospital de Câncer de Barretos, Barretos, Brasil. 3. Faculdade de Ciências da Saúde Dr Paulo Prata, Barretos, Brasil.

http://dx.doi.org/10.1590/1806-9282.66.3.257

\section{SUMMARY}

OBJECTIVE: The present study aims to compare medical students' quality of life (QoL) at two Brazilian institutions with different pedagogical conceptions.

METHODS: We studied students during the first four years of medical school at two institutions (one using active methodologies and small groups and the other using traditional lectures and large groups). We used a demographic questionnaire and the WHOQOL-BREF.

RESULTS: 820 medical students were included. No significant differences in quality of life were found in general, nor while evaluating the course phase, except for the physical WHOQOL, which was lower for 2nd-year students at the institution with traditional lectures, even when adjusted for gender.

CONCLUSION: Our findings revealed that, despite having very distinct pedagogical conceptions and characteristics, there were no significant differences in medical students' QoL scores between both institutions. These results are surprising and differ from our initial hypothesis, which expected better QoL for those using more active and student-centered methods.

KEYWORDS: Education, medical. Students, medical. Quality of life. Problem-based learning.

\section{INTRODUCTION}

Individual and medical education factors can have remarkable influences on students' wellbeing. Studies in different parts of the world have shown that medical students constitute a population at high risk for lower levels of quality of life and that medical schools are responsible for some of these outcomes ${ }^{1,2}$. The quality of life deterioration is associated with weak academic performance, lower motivation, and a decline in empathy, which, in turn, affects the doctor-patient relationship ${ }^{3}$.

Traditional curricula that present pedagogical strategies giving priority to expositive classes, with activities centered on the professor in a traditional model, have been used in Brazilian medical schools 
for many years and have been the object of criticisms and reflections ${ }^{2}$. On the other hand, student-centered curricula using strategies like Problem-Based Learning (PBL) and Team-Based Learning (TBL) have increasingly found their space in the changing paradigms now being implemented ${ }^{2}$.

Nevertheless, there are still doubts if active educational strategies may be responsible for better wellbeing outcomes ${ }^{1,4}$. Even though studies published in several countries have examined questions involving medical students' quality of life (QoL), few have compared students from different institutions by using the same instrument, in similar course phases and considering institutional peculiarities ${ }^{3,5}$.

Therefore, this study aims to compare medical students' QoL at two Brazilian schools with different pedagogical conceptions. Our hypothesis was that there would possibly be differences in the QoL of students subjected to different learning environments.

\section{METHODS}

This comparative study was undertaken during the first semester of 2016 involving students in the first through fourth years of medical schools at two Brazilian institutions. The study's objectives were explained to students during class time, and the questionnaires were applied in-person and online during the same period at both institutions.

Institution 1 (Dr. Paulo Prata School of Health Sciences at Barretos, FACISB) is a private institution. The school makes intense use of student-centered strategies like PBL and TBL, formative and summative assessments, is structured in cycles, and provide students with mentoring and psychological support. Institution 2 (the Federal University of Juiz de Fora, UFJF) is a public institution. It uses a model that presents traditional lectures and summative assessments, is structured around disciplines, and had neither a mentoring program nor a psychological support structure at the time the study was conducted. Both, at present, have 180 students per year. Further details concerning institutions' characteristics can be visualized in Table 1.

The questionnaire was self-reported and contained data related to gender, course year, age, and the WHOQOL-BREF instrument ${ }^{6}$. That scale, validated for Brazilian Portuguese, comprises 26 items, on a 5-point Likert scale, with four domains: physical, psychological, social relationships, and environment, and it is widely used in medical education ${ }^{6}$.

Statistical analysis was done using SPSS version 21. Chi-squared was used to analyze differences in gender, and the t-test for independent samples was used to compare age and quality of life scores (WHOQOL-BREF) for students at both schools. Since differences were found between genders at the two institutions, results were also controlled by gender.

The project was approved by the ethics committees at both UFJF and FACISB, and students signed a consent term.

\section{RESULTS}

A total of 820 medical students were included -277 out of $330(83.9 \%)$ from Institution 1 and 543 out of 720 (75.4\%) from Institution 2. Tables 2 and 3 present the demographic differences and WHOQOL-BREF scores for students at both institutions, respectively. Differences in gender $(\mathrm{p}=0.003)$, but not age $(\mathrm{p}=0.262)$, were found (Table 2). After comparing students' quality of life from the two schools, no significant differences were found in general nor while evaluating the course phase, except for the physical WHOQOL, which was lower for $2^{\text {nd }}$-year students at Institution 2 , even when adjusted for gender (Table 3 ).

\section{DISCUSSION}

Our findings revealed that, despite having very distinct pedagogical conceptions and characteristics, there were no marked differences in medical students' QoL scores between both institutions. These results are surprising and differ from our main hypothesis that expected better QoL for those using more active and student-centered methods.

In a recent study, the QoL scores for students at an American medical school (Southern Illinois University) and another in Brasil (the very same UFJF that participated in this study) were compared. Greater scores were found for the environment and social WHOQOL domains of American students when compared with Brazilian students. The latter showed a greater quality of physical health, probably because of the younger age at which Brazilian students enter medical school. In researching possible reasons for the differences found, US students were older (more mature) and experienced smaller class sizes, earlier patient encounters, problem-based learning, and psychological support ${ }^{7}$.

Curiously, despite the Brazilian institution 
TABLE 1. INSTITUTIONAL CHARACTERISTICS OF TWO BRAZILIAN MEDICAL SCHOOLS

\begin{tabular}{|c|c|c|}
\hline Characteristics & $\begin{array}{l}\text { Dr. Paulo Prata School of Health Sciences at } \\
\text { Barretos }\end{array}$ & $\begin{array}{l}\text { Federal University of Juiz de Fora School of } \\
\text { Medicine }\end{array}$ \\
\hline Total course length (in hours) & 8440 hours (for all 6 years) & 7,745 hours (for all 6 years) \\
\hline $\begin{array}{l}\text { Average hours of student activities } \\
\text { at medical school per week, years } 1 \\
\text { through } 4\end{array}$ & 32/week & 34/week \\
\hline Number of students/year & $\begin{array}{l}\text { Beginning in } 2012 \text {, admission of two initial groups } \\
\text { of } 30 \text { students, followed by another two groups of } \\
60 \text {, and, currently, } 90 \text { students/year }\end{array}$ & 90/year \\
\hline Curriculum & $\begin{array}{l}\text { Made up of curricular components: Modules, } \\
\text { Curricular Units, Medical Internships - Curricular } \\
\text { Stages and Optional Components, organized in } \\
12 \text { semesters with } 2 \text { learning cycles: Cycle I - Basic } \\
\text { Clinical Integration (semesters } 1 \text { through 8) and } \\
\text { Cycle II - clerkship (semesters } 9 \text { through 12) }\end{array}$ & $\begin{array}{l}\text { Organized by subject (Anatomy, Physiology, } \\
\text { Semiology, etc.), divided into pre-clinical, clinical } \\
\text { and clerkship phases ( } 2 \text { years each) }\end{array}$ \\
\hline Teacher/student ratio & $\begin{array}{l}\text { Theoretical class - 30-90 student per teacher } \\
\text { Practical - varies, most practical classes have 15- } \\
30 \text { students per teacher }\end{array}$ & $\begin{array}{l}\text { Theoretical class - } 90 \text { students per teacher } \\
\text { Practical - varies, most practical classes have 20- } \\
25 \text { students per teacher }\end{array}$ \\
\hline $\begin{array}{l}\text { Content Delivery (lecture, laboratory, } \\
\text { clinical, etc.) }\end{array}$ & $\begin{array}{l}\text { Based on modules for learning objectives with } \\
\text { active search for knowledge, practical activities in } \\
\text { laboratory environment, and realistic simulations; } \\
\text { few lectures. Clerkship, strongly practical, years } \\
5 \text { to } 6\end{array}$ & $\begin{array}{l}\text { Strongly theoretical, lecture-based, from years } 1 \text { to } \\
4 \text {, with some practical activities. Strongly practical } \\
\text { from years } 5 \text { to } 6\end{array}$ \\
\hline Methodology or Pedagogical Model & $\begin{array}{l}\text { Mostly active (TBL and PBL). Lectures at a few } \\
\text { points }\end{array}$ & $\begin{array}{l}\text { Mostly Traditional. } 30 \text { hours of PBL per year } \\
\text { Includes TBL and flipped classroom at a few } \\
\text { points }\end{array}$ \\
\hline Assessment & $\begin{array}{l}\text { Cognitive assessment based on clinical cases from } \\
\text { year } 1 \text { on, clinical skills and gestures. Formative in } \\
\text { specific subjects, humanistic-behavioral involve- } \\
\text { ment }\end{array}$ & $\begin{array}{l}\text { Mostly summative with cognitive assessment. } \\
\text { Formative is limited to some subjects: one disci- } \\
\text { pline has OSCE (year } 3 \text { ) and another has long case } \\
\text { (year } 1 \text { ) }\end{array}$ \\
\hline Mentoring & Yes & No \\
\hline Student representation & $\begin{array}{l}\text { Has the following organized student groups: } \\
\text { - physical activities (Atlética) } \\
\text { - academic activities (DA) } \\
\text { - religious activities (GOL and ONDA) }\end{array}$ & $\begin{array}{l}\text { Has the following organized student groups: } \\
\text { - physical activities (Atlética) } \\
\text { - academic activities (DA) } \\
\text { - religious activities } \\
\text { - sports activities } \\
\text { - musical activities }\end{array}$ \\
\hline Primary Health Care & Students have some contact, beginning in year 1 & $\begin{array}{l}\text { Students have some contact beginning in year } 1 . \\
\text { However, they have more contact during clerk- } \\
\text { ship, when on a team }\end{array}$ \\
\hline $\begin{array}{l}\text { Medical support for students (pro- } \\
\text { vided by medical school) }\end{array}$ & No & No \\
\hline $\begin{array}{l}\text { Psychological support for students } \\
\text { (provided by medical school) }\end{array}$ & $\begin{array}{l}\text { Yes. Psychological support for students (provided } \\
\text { by medical school) from year } 1 \text { on, via referral by } \\
\text { psycho-pedagogical department }\end{array}$ & No \\
\hline $\begin{array}{l}\text { Medical student well-being/wellness } \\
\text { program }\end{array}$ & No & No \\
\hline Well-being day & No & No \\
\hline $\begin{array}{l}\text { Workshops and presentations pro- } \\
\text { moting wellness }\end{array}$ & No & $\begin{array}{l}\text { Yes, beginning in 2017. Cohort used in study did } \\
\text { not have this. }\end{array}$ \\
\hline Library & Yes & Yes \\
\hline Fitness Center for students & No & No \\
\hline Student lounge & Yes, inside building with armchairs for rest and TV. & Yes, inside building (TV, snooker table, tennis) \\
\hline Free wi-fi & Yes & Yes \\
\hline Mental health screening & Yes & No \\
\hline Student Life Advising & No & No \\
\hline $\begin{array}{l}\text { Mindfulness Based Stress Reduction } \\
\text { Program }\end{array}$ & No & Yes \\
\hline Student Parties & Yes, off campus & Yes, off campus \\
\hline Cafeteria & Yes & Yes \\
\hline Parking lots & Yes, for teachers and students & $\begin{array}{l}\text { Only for professors at medical school } \\
\text { Student parking available at a distance of } 500 \\
\text { meters ( } 1640 \text { feet). Seen as a great problem }\end{array}$ \\
\hline Other well-being initiatives & No & - Live Music for students (once a week) \\
\hline
\end{tabular}


TABLE 2. COMPARISON BETWEEN STUDENTS AT INSTITUTIONS 1 (DR. PAULO PRATA SCHOOL OF HEALTH SCIENCES AT BARRETOS) AND 2 (FEDERAL UNIVERSITY OF JUIZ DE FORA SCHOOL OF MEDICINE)

\begin{tabular}{|c|c|c|c|}
\hline & Institution $1(n=277)$ & Institution $2(n=543)$ & \\
\hline Age $^{*}$ & $21.41(2.77)$ & $21.18(2.73)$ & 0.262 \\
\hline \multicolumn{4}{|l|}{ Gender } \\
\hline Male & $94(33.9 \%)$ & $244(44.9 \%)$ & \\
\hline Female & $183(66.1 \%)$ & $299(55.1 \%)$ & 0.003 \\
\hline \multicolumn{4}{|l|}{ Year } \\
\hline 1st & 118 (42.8\%) & $152(28.0 \%)$ & \\
\hline 2nd & $59(21.4 \%)$ & $116(21.4 \%)$ & \\
\hline $3 r d$ & $51(18.5 \%)$ & $142(26.2 \%)$ & \\
\hline 4 th & $48(17.4 \%)$ & $133(24.5 \%)$ & $<0.001$ \\
\hline
\end{tabular}

TABLE 3. COMPARISON BETWEEN WHOQOL-BREF SCORES FOR STUDENTS AT INSTITUTIONS 1 (DR. PAULO PRATA SCHOOL OF HEALTH SCIENCES AT BARRETOS) AND 2 (FEDERAL UNIVERSITY OF JUIZ DE FORA SCHOOL OF MEDICINE)

\begin{tabular}{|c|c|c|c|}
\hline & Institution $1(\mathrm{n}=277)$ & Institution $2(n=543)$ & \\
\hline Domains & Mean $(\mathrm{SE})^{\star \star}$ & Mean $(\mathrm{SE})^{\star \star}$ & $\mathrm{p}$ \\
\hline \multicolumn{4}{|c|}{ All years } \\
\hline WHOQOL - Physical & 13.85(0.14) & 13.75(0.10) & 0.593 \\
\hline WHOQOL -Psychological & $13.36(0.15)$ & $13.62(0.10)$ & 0.162 \\
\hline WHOQOL - Social & $14.09(0.19)$ & $14.53(0.13)$ & 0.069 \\
\hline WHOQOL - Environment & $14.09(0.13)$ & $14.17(0.09)$ & 0.622 \\
\hline \multicolumn{4}{|c|}{ 1st year } \\
\hline WHOQOL - Physical & $13.06(0.22)$ & $13.40(0.20)$ & 0.260 \\
\hline WHOQOL - Psychological & $12.85(0.22)$ & $13.34(0.19)$ & 0.099 \\
\hline WHOQOL - Social & $13.58(0.30)$ & $14.28(0.26)$ & 0.084 \\
\hline WHOQOL - Environment & $13.62(0.20)$ & $14.14(0.18)$ & 0.061 \\
\hline \multicolumn{4}{|c|}{ 2nd year } \\
\hline WHOQOL - Physical & $14.54(0.30)$ & $13.14(0.21)$ & $<0.001$ \\
\hline WHOQOL - Psychological & $13.45(0.33)$ & $12.95(0.23)$ & 0.230 \\
\hline WHOQOL - Social & $14.06(0.43)$ & $13.99(0.30)$ & 0.894 \\
\hline WHOQOL - Environment & $14.21(0.30)$ & $13.54(0.21)$ & 0.075 \\
\hline \multicolumn{4}{|c|}{ 3rd year } \\
\hline WHOQOL - Physical & $14.81(0.35)$ & $14.04(0.20)$ & 0.061 \\
\hline WHOQOL - Psychological & $14.57(0.34)$ & $13.93(0.20)$ & 0.113 \\
\hline WHOQOL - Social & $15.38(0.42)$ & $15.10(0.25)$ & 0.570 \\
\hline WHOQOL - Environmental & $14.79(0.32)$ & $14.45(0.19)$ & 0.374 \\
\hline \multicolumn{4}{|c|}{ 4th year } \\
\hline WHOQOL - Physical & $14.04(0.32)$ & $14.36(0.19)$ & 0.405 \\
\hline WHOQOL - Psychological & $13.38(0.33)$ & $14.15(0.20)$ & 0.052 \\
\hline WHOQOL - Social & $14.18(0.43)$ & $14.65(0.26)$ & 0.358 \\
\hline WHOQOL - Environmental & $14.48(0.29)$ & $14.44(0.18)$ & 0.907 \\
\hline
\end{tabular}

** Mean adjusted for gender

analyzed in that study having some characteristics like the American one, including the use of the PBL model, the results were different from those found in the Brasil-USA comparison. If, on one hand, some studies have shown that PBL curriculums can lead to a reduction in psychological disorder and an increase in students' general satisfaction ${ }^{4}$, other have also demonstrated that this specific method can cause high levels of stress and anxiety, motivated by students' doubts about the consistency of their education $^{1}$. Thus, the way the teaching strategy is linked is fundamental for students' good or poor outcomes. Personal and cultural factors seem to also exercise a determinant influence on QoL scores and should be 
taken into consideration by educators.

This study has some limitations that should be considered. It involved only two schools (a public and a private), meaning that one should be cautious when generalizing its findings. Although we recognize that students from private medical schools have a better socioeconomic status and tend to have a better quality of life, it is surprising that we found no differences between the institutions. Therefore, both socioeconomic aspects and pedagogical conceptions seem to have little influence on the quality of life of these students. The identification of predictive factors was also not part of the study's design. Future studies can use learning environment scales to identify these factors.

It is concluded that, despite the differences between the two institutions in both the pedagogical conceptions used and in offering mentoring and psychological support, in practical terms, the two populations are similar regarding the quality of life. These findings can be explained by the array of factors involving the promotion of quality of life that go beyond pedagogical conceptions choices for medical education, choices which are, in and of themselves, highly stressful.

\section{Author contributions}

Oscarina da Silva Ezequiel: Substantial contributions to the study concept and design. Data analysis and interpretation. Drafting of the article. Approval of the final version for publication. Accountability for all aspects of this study, assuring that all aspects related to the exactness and integrity of all its parts are dully investigated and resolved.

Bianca Sakamoto Ribeiro Paiva: Substantial contributions to the study concept and design. Data interpretation. Critical review of the study with relevant intellectual input. Approval of the final version for publication. Accountability for all aspects of this study, assuring that all aspects related to the exactness and integrity of all its parts are dully investigated and resolved.

Carlos Eduardo Paiva: Substantial contributions to the study concept and design. Data interpretation. Critical review of the study with relevant intellectual input. Approval of the final version for publication. Accountability for all aspects of this study, assuring that all aspects related to the exactness and integrity of all its parts are dully investigated and resolved.

Ivana Lúcia Damásio Moutinho: Substantial contributions to the study concept and design. Data collection and interpretation. Critical review of the study with relevant intellectual input. Approval of the final version for publication. Accountability for all aspects of this study, assuring that all aspects related to the exactness and integrity of all its parts are dully investigated and resolved.

Robson Aparecido dos Santos Boni: Substantial contributions to the study concept and design. Data collection and interpretation. Critical review of the study with relevant intellectual input. Approval of the final version for publication. Accountability for all aspects of this study, assuring that all aspects related to the exactness and integrity of all its parts are dully investigated and resolved.

Giancarlo Lucchetti: Substantial contributions to the study concept and design. Data collection and interpretation. Drafting of the text. Approval of the final version for publication. Accountability for all aspects of this study, assuring that all aspects related to the exactness and integrity of all its parts are dully investigated and resolved.

\section{Funding}

None.

\section{Conflicts of interest}

No potential conflict of interest relevant to this article was reported.

\section{RESUMO}

OBJETIVO: O presente estudo tem como objetivo comparar a qualidade de vida (QV) de estudantes de medicina de duas instituições brasileiras com diferentes concepções pedagógicas.

MÉTODOs: Estudo comparativo incluindo estudantes do $1^{\circ}$ ao $4^{\circ}$ ano do curso de medicina de duas instituições no Brasil (uma usando metodologias ativas e pequenos grupos e a outra aulas expositivas tradicionais e grandes grupos). Utilizou-se um questionário demográfico e o instrumento WHOQOL-Bref.

RESULTADOS: Foram incluídos 820 estudantes de medicina. Nenhuma diferença significativa na qualidade de vida foi encontrada no geral e na avaliação por fase do curso, com exceção do WHOQOL físico, que mostrou ser mais baixo para os estudantes da da instituição com aulas tradicionais, mesmo quando ajustado para o gênero. 
CONCLUSÃO: Nossos achados revelaram que apesar de terem concepções e características pedagógicas bem distintas, não se observaram diferenças significativas nos escores de QV dos estudantes de medicina das duas instituições. Esses resultados são surpreendentes e diferem da nossa principal hipótese, uma vez que esperávamos uma melhora de QV para aqueles que usam métodos mais ativos e centrados no estudante.

PALAVRAS-CHAVE: Educação médica. Estudantes de medicina. Qualidade de vida. Aprendizagem baseada em problemas.

\section{REFERENCES}

1. Moffat KJ, McConnachie A, Ross S, Morrison JM. First year medical student stress and coping in a problem-based learning medical curriculum. Med Educ. 2004;38(5):482-91.

2. Paro $\mathrm{HB}$, Morales $\mathrm{NM}$, Silva $\mathrm{CH}$, Rezende $\mathrm{CH}$, Pinto $\mathrm{R}$, Morales $\mathrm{RR}$, et al. Health-related quality of life of medical students. Med Educ. 2010;44(3):227-35.

3. Jamali A, Tofangchiha S, Jamali R, Nedjat S, Jan D, Narimani A, et al. Medical students' health-related quality of life: roles of social and behavioural factors. Med Educ. 2013;47(10):1001-12.

4. Kiessling C, Schubert B, Scheffner D, Burger W. First year medical students perceptions of stress and support: a comparison between reformed and traditional track curricula. Med Educ. 2004;38(5):504-9.
5. Seweryn M, Tyrała K, Kolarczyk-Haczyk A, Bonk M, Bulska W, Krysta K. Evaluation of the level of depression among medical students from Poland, Portugal and Germany. Psychiatr Danub. 2015;27(Suppl 1):S216-22.

6. Skevington SM, Lotfy M, O'Connell KA; WHOQOL Group. The World Health Organization's WHOQOL-BREF quality of life assessment: psychometric properties and results of the international field trial. A report from the WHOQOL group. Qual Life Res. 2004;13(2):299-310.

7. Lucchetti G, Damiano RF, DiLalla LF, Lucchetti ALG, Moutinho ILD, Silva Ezequiel $O$, et al. Cross-cultural differences in mental health, quality of life, empathy, and burnout between US and Brazilian medical students. Acad Psychiatry. 2018;42(1):62-7. 